\title{
DINAMIKA KEBIJAKAN TRANSPORTASI ONLINE
}

\author{
Faris Widiyatmoko, S.Sos., M.KP \\ Peneliti di Politika Research Center (PRC) \\ dan Alumni Pascasarjana Universitas Airlangga Surabaya
}

Email:faris.widiyatmoko.fw@gmail.com

\begin{abstract}
Abstrak
Perkembangan transportasi daring telah memberikan tantangan terhadap sektor kebijakan publik untuk dapat mengikuti perkembangan teknologi informasi. Namun, pemerintah sebagai regulator terlihat gagap menemukan peraturan yang tangkas untuk menghadapi fenomena transportasi daring tersebut. Artikel ini akan mengurai dinamika kebijakan pengaturan transportasi daring dan dampaknya terhadap masyarakat. Sampai saat ini setidaknya telah dilakukan tiga kali revisi atau perbaikan terhadap Peraturan Menteri Perhubungan (Permenhub) yang mengatur transportasi daring, yaitu Permenhub No. 32 Tahun 2016, Permenhub No. 27 Tahun 2017 dan Permenhub 108 Tahun 2017. Namun demikian, pro dan kontra masih saja muncul terkaitdengan transportasi daring tersebut karena minimnya kebijakan yang lebih terintegrasi dan komprehensif yang mengikutsertakan berbagai kementerian dan lembaga terkait untuk merumuskan dan melaksanakan kebijakan tentang transportasi daring. Karena itu, pelibatan berbagai aktor dan kelompok kepentingan perlu untuk diperhatian lebih baik, karena merekalah yang akan menerima dampak kebijakan dan melaksanakan kebijakan itu sendiri. Apalagi masyarakat digital yang menggunakan bantuan teknologi informasi untuk melakukan aktifitas kesehariannya memiliki ciri yang berbeda dengan kondisi masyarakat sebelumnya. Transportasi daring telah berhasil mendorong perubahan sosial dalam tiga tingkatan, yaitu tingkat individu, tingkat antar-individu dan tingkat komunitas.
\end{abstract}

Kata Kunci : Dinamika Kebijakan, Transportasi Online, Perubahan Sosial

\begin{abstract}
The development of online transportation has posed a challenge to the public policy sector to be able to keep abreast of information technology. However, the government as a regulator seems to stutter to find agile regulations to deal with the phenomenon of online transportation. This article will outline the dynamics of online transportation regulation policies and their impact on society. Until now, at least three revisions or improvements have been made to the Minister of Transportation (Permenhub) Regulation which regulates online transportation, namely Permenhub No. 32 of 2016, Permenhub No. 27 of 2017 and Minister of Transportation 108 of 2017. Nevertheless, the pros and cons still arise related to online transportation because of the lack of more integrated and comprehensive policies that include various relevant ministries and institutions to formulate and implement policies on online transportation. Therefore, the involvement of various actors and interest groups needs to be considered better, because they will receive the impact of the policy and implement the policy itself. Moreover, the digital community that uses information technology assistance to carry out their daily activities has characteristics that are different from the conditions of the previous community. Online transportation has succeeded in encouraging social change in three levels, namely the individual level, the inter-individual level and the community level.
\end{abstract}

Key Word : Policy Dynamics, Online Transportation, Social Change 


\section{LATAR BELAKANG}

Perkembangan teknologi informasi dan komunikasi telah menyebar ke berbagai sektor kehidupan, salah satunya adalah sektor transportasi publik. Pertumbuhan penduduk di daerah urban telah memberikan tantangan kepada pemerintah dan kebijakan publik, terutama dalam isu penggunaan lahan dan transportasi publik (Mercier, 2009). Di Indonesia kemunculan transportasi berbasis aplikasi atau transportasi daring telah menimbulkan kegaduhan dan konflik diantara pemangku kepentingan di sektor transportasi. Namun keberadaan transportasi daring adalah sebuah keniscahyaan dari perkembangan terknologi informasi atau biasa disebut sebagai revolusi teknologi 4.0, keberadaanya secara serius memberikan tantangan terhadap transportasi konvensional yang telah beroperasi lebih dahulu.

Kemunculan transportasi berbasis aplikasi atau biasa disebut sebagai transportasi daring (online) telah memberikan alternatif kepada konsumen. Transportasi daring mampu memberikan layanan yang baik, kemudahan keterjangkauan, harga yang murah atau kepastian harga dan kemudahan akses bagi konsumen. Sehingga kemunculannya telah menggangu pihak incumbent dalam konteks ini adalah transportasi konvensional. Tantangan dengan mengunakan perkembangan teknologi informasi yang diusung oleh transportasi daring telah berhasil mengubah peta permainan pada sektor usaha transportasi. Namun seiring dengan kemunculan dan perluasannya, konflik antara transportasi daring dan transportasi konvensional mengemuka di beberapa daerah.

Konflik sosial yang terjadi akibat keberadaan transportasi daring dapat dilihat pada pemberitaan media massa, baik cetak maupun daring (sebagai contoh lihat Koran Kompas, 22 Maret 2017). Ketidakadilan dan diskrimiasi pemberlakuan peraturan antara transportasi daring dan transportasi konvensional menjadi salah satu akar persoalan yang memunculkan konflik. Selain itu, berkurangnya pendapatan pengemudi transportasi konvensional, hingga bisa mencapai 70\%, membuat konflik sosial diantara pemangku kepentingan jasa transportasi menjadi tidak dapat dihindari (Istianto dan Mualamin, 2017).

Terdapat beberapa penelitian yang memberikan perhatian terhadap transportasi daring. Sebagian penelitian terdahulu menyoroti perubahan yang ditimbulkan oleh transportasi daring dalam konteks persaingan bisnis transportasi di Indonesia (Putri, 2018; Wahyuningtyas, 2016). Konteks kesejahteraan pengemudi juga mendapatkan perhatian oleh sebagian peneliti, baik dampak adanya transportasi daring terhadap pendapatan pengemudi transportasi konvensional, dan kesejahteraan pengemudi transportasi daring yang diukur dari upah yang dihasilkan dari produktivitas kerjanya (Qisthi, 2018; Ramadhan, 2017). Penelitian lainnya, berusaha membandingkan kebijakan di Jakarta dan Singapura dalam merespon keberadaan transportasi daring (Samudro, 2017). Masih belum terdapat peneliti yang berfokus pada dinamika perubahan-penrubahan pengaturan tentang kebijakan transportasi daring, serta dampaknya terhadap kehidupan sosial masyarakat.

Peneliti terdahulu juga menaruh perhatian terhadap aspek gender dalam kemunculan transportasi daring. Keberadaan Go-Jek yang telah menyebar secara masif di berbagai daerah di Indonesia juga turut mengikutsertakan perempuan sebagai pengemudi. Sebuah penelitian memberikan perhatian terhadap perlakukan yang diberikan oleh perusahaan terhadap mitra pengemudi perempuan, serta stigma masyarakat terhadap mereka (Darmawati, 2018). Akan tetapi penelitian ini tidak akan membahas mengenai isu gender dalam artikel ini. Namun peneliti juga mengakui pentingnya persoalan gender dalam masifnya perkembangan teknologi informasi di sektor jasa transportasi. 
Fenomena transportasi daring memberikan peluang dan tantangan bagi pemerintah. Tantangan terutama berada dalam konteks kesiapan kebijakan publik untuk meresponnya. Pemerintah masih mencari langkah terbaik untuk melakukan pengaturan, padahal sebelumnya beberapa pemerintah di level daerah pernah melarang beroperasinya transportasi berbasis aplikasi. Peluangan dari keberadaan transportasi daring berkaitan dengan tenaga kerja, ekonomi berbagi, dan disrupsi terhadap sistem transportasi yang ada sebelumnya. Disrupsi secara sederhana menurut Christensen dapat dipahami sebagai tergantikannya 'pasar lama' oleh sebuah 'pasar baru' yang menghasilkan kebaruan dan jauh lebih efisien dengan ciri utama, yaitu destruktif dan kreatif (dalam Kasali, 2017).

Kemunculan transportasi daring juga memunculkan permasalahan baru, terutama berbicara mengenai pengemudi. Riset yang dilakukan oleh Nastiti (2016) menunjukkan tiga isu krusial yang harus dihadapi oleh pengemudi transportasi daring, pertama adalah otomatisasi kontrol. Pengemudi transportasi online berdasarkan riset tersebut, berada dalam pola yang disebut sebagai "gamification of work", dimana pengemudi harus bekerja lebih keras dan lebih lama sembari mengkalkulasi poin, bonus, persentase performa dan rating agar mendapatkan upah yang cukup. Kedua isu ilusi "kemitraan", pada posisi ini pengemudi sebagai mitra diharuskan menyertakan alat produksinya (kendaraan), serta menanggung biaya perawatan, asuransi kendaraan, bahan bakar kendaraan, parkir dan sebagainya, namun mereka berada pada posisi dalam hierarki yang terendah. Perusahaan atau aplikator berada dipuncak kekuasaan dengan kuasa terhadap teknologi, modal dan akses, sementara penumpang bertindak sebagai "manager" karena rating yang mereka berikan menentukan bonus bagi pengemudi. Pada posisi inilah pengemudi sering berada dalam kondisi yang kurang menguntungkan, karena jika terdapat perselisihan dengan pelanggan hampir dapat dipastikan pengemudi harus menanggung akibatnya. Ketiga adalah isu kekosongan hukum, ketiadaan aturan yang berlaku membuat pengemudi tidak mendapatkan perlindungan hukum sebagaimana seharunya. Hubungan relasi kerja semi informal gaya baru yang muncul seperti industri transportasi daring, penting kiranya peraturan perundangundangan untuk merespon agar pengemudi tidak terjebak pada eksploitasi akibat kekosongan hukum.

Masyarakat yang sebagian besar mulai menggantungkan aktivitas keseharian dengan menggunakan bantuan teknologi informasi memunculkan ciri tersendiri. Misalnya, penggunaan jasa transportasi dengan menggunakan Go-Jek dan Grab, yang dirasa lebih memberikan kemudahan dan efisiensi bagi penggunanya. Perkembangan era masyarakat digital saat ini, mengingatkan kepada argumen dari Toffler (1980) yang membagi masa transisi era perkembangan di masyarakat menjadi tiga, yaitu era masyarakat agraris, era masyarakat industri, dan terakhir era masyarakat komunikasi. Pada era masyarakat digital, komunikasi kita semakin tidak terbatas pada sekat ruang-ruang dunia nyata. Pada masyarakat digital ruang-ruang tersebut melebur atau tidak menjadi penghalang sama sekali untuk berkomunikasi. Hal ini terlihat dengan jelas, ketika kita bisa melakukan pemesanan makanan atau minuman, membeli pakaian, bahkan membeli saham, hanya dengan melalui dawai jaringan internet atau daring.

Pemerintah telah merespon kemunculan transportasi daring dengan mengeluarkan Peraturan Menteri Perhubungan (Permenhub). Meskipun peraturan yang berusaha mengatur transportasi daring tersebut masih menimbulkan pro dan kontra di masyarakat. Para pemangku kepentingan di sektor jasa transportasi juga masih belum menemui titik kesepahaman yang baik tentang peraturan yang akan diberlakukan. Hal ini berdampak pada implementasi kebijakan yang tidak maksimal, 
sebagaimana dapat terlihat pada perubahan atau revisi pada kebijakan yang mengatur transportasi daring. Oleh karena itu, penelitian ini berusaha untuk menunjukkan dinamika kebijakan transportasi daring, serta bagaimana transportasi daring mempengaruhi pengguna jasa transportasi publik dalam masyarakat digital.

\section{DINAMIKA KEBIJAKAN TRANSPORTASI DARING}

Aplikator transportasi daring adalah jasa perantara atau dapat pula disebut sebagai two-sided market (pasar dua sisi), pembaharuan yang dilakukannya adalah digunakannya teknologi informasi sehingga menjadikannya lebih efisien dan skala bisnis menjadi lebih luas. Jika mengacu realitas tersebut maka dapat dipahami mengapa peraturan yang ada masih belum cukup tangkas untuk mengatasinya. Karena peraturan yang ada diperuntukkan untuk mengatur pasar satu sisi dan bukannya pasar dua sisi sebagaimana fenomena transportasi daring mengemuka.

Aplikator transportasi daring, seperti Go-Jek dan Grab, dengan demikian tidak berada dalam naungan Kementerian Perhubungan (Kemenhub), melainkan berada dalam naungan Kementerian Komunikasi dan Indormatika (Kemenkominfo). Karena aplikator bersitegas bahwa dirinya bukannya perusahaan jasa transportasi tetapi perusahaan teknologi yang mempertemukan penguna jasa tranpsortasi dan penyedia jasa transportasi. Go-Jek dan Grab sendiri tidak menyediakan kendaraan sebagai alat transportasi, para pengemudilah yang menyediakan sekaligus menjadi pemilik alat transportasi tersebut.

Sanggahan bahwa Go-Jek bukanlah perusahaan jasa transportasi, dapat dijelaskan melalui salah satu petikan wawancara yang disampaikan oleh Nadiem Makarim selaku CEO Go-Jek, "Kami percaya diri kami adalah perusahaan teknologi, bukan transportasi, dan kami ingin men-sharing teknologi tersebut kepada pemain lain (Kresna, 2017)." Bantahan bahwa Go-Jek bukanlah perusahaan jasa transportasi sudah cukup sering dan berulang kali disampikan. Namun melihat bagaimana cara kerja dari aplikator transportasi daring saat ini, sepertinya klaim yang sudah disampaikan tersebut telah melanggar salah satu pasal dalam Undang-Undang Lalu Lintas dan Angkutan Jalan (UU LLAJ), yaitu UU 22/2009 pasal 183.

Pemerintah mengetahui betul tantangan bahwa model bisnis yang diusung Go-Jek dan Grab berbeda dengan perusahaan jasa transportasi yang sudah lebih dahulu ada. Namun pemerintah tidak bisa berbuat banyak untuk melawan kehendak pasar, disamping itu para mitra pengemudi yang sudah semakin banyak menjadi daya tawar tersendiri bagi aplikator untuk mendapatkan kemudahan dalam menjalankan bisnisnya. Konsumen yang sebagian besar adalah kelompok kelas menengah di daerah urban maupun rural-urban merasa mendapatkan manfaat dari keberadaan Go-Jek dan Grab, sehingga mereka juga memberikan dukungan terhadap eksistensi kedua perusahaan tersebut. Jika memang kemudian, Go-Jek dan Grab adalah perusahaan teknologi dan bukan perusahaan transportasi maka pemerintah segera perlu merumuskan kebijakan yang lebih komprehensif, lebih dari Permenhub. Namun jika aplikator beralih menjadi perusahaan jasa transportasi, maka Permenhub sudah lebih dari cukup untuk memberikan kepastian hukum.

Konsekuensi yang harus ditanggung oleh aplikator jika berubah statusnya menjadi perusahaan jasa transportasi adalah para pengemudi secara otomatis akan menjadi karyawan. Hal ini sepertinya yang dikhawatirkan oleh Go-Jek dan Grab, karena beban mereka akan bertambah sesuai dengan jumlah pengemudi. Kemudian, status 'kemitraan' yang selama ini digencarkan akan hilang secara otomatis. Hilangnya status kemitraan ini juga 
dikhawatirkan oleh para pengemudi, karena relasi yang terjadi akan lebih mirip seperti buruh dan majikan jika status kemitraan. Namun demikian status kemitraan juga masih menimbulkan ketidakpastian stautus dan hubungan kerja antara pengemudi dan aplikator. Hal itu terlihat pada pembahasan sebelumnya tentang ilusi 'kemitraan'. Oleh karena itu, dikalangan pengemudi sendiri, status hubungan kerja kemitraan masih menjadi perdebatan yang hangat.
Melalui hubungan kerja kemitraan yang dimungkinkan melalui adanya sharing economy (ekonomi berbagi) yang diciptakan aplikator angkutan daring membuat hubungan kerja diantara mitra pengemudi daring dan aplikator angkutan daring menjadi berbeda dengan angkutan konvensional. Dalam jangka pendek keuntungan yang didapat oleh pengemudi angkutan daring terlihat menjanjikan, namun dalam jangka panjang kemungkinan besar pendapatan tersebut tidak

Tabel 1 : Perbandingan Tanggung Jawab Aplikator Taksi Daring (Go-Jek) dan Perusahaan Taksi Konvensional

\section{Tangung Jawab Go-Jek}

Pengendara Go-Jek adalah mitra, bukan agen, pegawai atau perwakilan perusahaan.

Go-Jek tidak bertanggung jawab secara langsung atas kecelakaan yang mengakibatkan kerusakan kendaraan atau luka badan.

Ada asuransi untuk pengemudi (tidak wajib). Dengan syarat membayar Rp. 15 ribu perbulan.

PT Aplikasi Anak Bangsa memberikan santunan kepada pelanggan Go-Jek hingga Rp. 10 juta dan biaya rumah sakit Rp. 5 juta.

\section{Tanggung Jawab Taksi Konvensional}

Perawatan berkala armada dibengkel Blue Bird gratis.

Mess untuk pengemudi di tiap pool.
Go-Jek memberikan biaya ganti rugi untuk kehilangan barang hingga Rp. 10 juta

Memberikan bonus poin kepada pengemudi jika mencapai target sebelum pukul 00.00, bonus pada setiap kota berbeda.

Go-Jek Swadaya, program yang ditujukan untuk pengemudi, seperti diskon kebutuhan operasional, akses asuransi dan perbankan, cicilan rumah, dsb. Grab juga memiliki program serupa melalui Grab Sejahtera.
Beasiswa untuk anak pengemudi.

Pinjaman untuk renovasi rumah, pembelian kendaraan bermotor, dan jaminan kesehatan hingga anak ketiga.

Kesempatan umrah bagi pengemudi.

Program kepemilikan mobil dengan kemudahan tanpa uang muka, bebas setoran delapan hari per bulan, dan cicilan menurun tiap tahun.

Setoran bagi pengemudi, Blue Bird Rp. 350 ribu dan Express Transindo Rp. 150 ribu tahun 2017.

Sumber : Koran Kompas, 3-4-2018 (data diolah). 
menguntungkan bagi pengemudi. Karena pengemudi angkutan daring harus menanggung segala resiko sendiri, seperti jaminan kesehatan, jaminan keselamatan, servis kendaraan, dan sebagainya. Berikut disajikan pada tabel data mengenai perbandingan tanggung jawab aplikator taksi daring dan perusahaan taksi konvensional. Perbandingan ini hanya untuk kendaraan beroda empat atau disebut sebagai taksi, dan hanya pada aplikator Go-Jek bukan Grab.

Pengemudi Go-Jek disebut sebagai mitra Go-Jek, sehingga mereka bukanlah agen, bawahan, buruh atau karyawan pada Go-Jek. Jika terjadi kecelakaan yang mengakibatkan kerusakan kendaraan atau luka badan, Go-Jek tidak memiliki kewajiban untuk bertanggung jawab secara langsung. Terdapat asuransi bagi pengemudi Go-Jek dengan syarat melakukan pembayaran Rp. 15 ribu setiap bulannya. Go-Jek memberlakukan sistem bonus bagi pengemudinya sampai dengan waktu yang telah ditentukan sebelumnya. Sementara itu, terlihat tangung jawab perusahaan taksi konvensional terhadap pengemudinya jauh lebih berat, seperti menyediakan bengkel kendaraan, mess bagi pengemudi, beasiswa bagi anak pengemudi, pinjaman bagi pengemudi, jaminan kesehatan, kesempatan umrah, dan sebagainya. Namun pengemudi taksi konvensional memiliki kewajiban untuk melakukan setoran kepada perusahaan sebagaimana telah ditentukan oleh perusahaan jasa transportasi konvensional. Kewajiban setoran inilah yang membedakan dengan transportasi daring, pada transportasi daring setoran ini disebut sebagai sharing pendapatan antara mitra pengemudi dan aplikator.

Go-Jek tidak tinggal diam melihat berbagai kritikan yang ditujukan kepada perusahaan tersebut mengenai hubungan kerjanya dengan mitra pengemudi. Maka mereka melakukan inovasi dengan mengeluarkan program Go-Jek Swadaya. Terdapat beberapa menu yang dapat dipilih oleh pengemudi melalui Go-Jek Swadaya, seperti diskon untuk kebutuhan operasional, akses asuransi dan perbankan, serta program cicilan rumah untuk mitra pengemudi. Grab sebagai pesaing utama Go-Jek juga melakukan inovasi serupa, dengan mengeluarkan program Grab Sejahtera. Dengan demikian maka dapat dilihat bahwa untuk mempertahankan eksistensinya dan menghadapi berbagai tuntutan pengemudi, Go-Jek dan Grab telah melakukan serangkain pembaharuan dan kerjasama dengan pihak lain untuk meningkatkan kesejahteraan mitra pengemudinya.

Perubahan atau revisi turut mewarnai perjalanan pengaturan pemerintah terhadap transportasi daring melalui Permenhub. Tidak hanya revisi, pembatalan Mahkamah Agung terhadap beberapa pasal yang terdapat dalam Permenhub yang mengatur transportasi daring ikut memberikan warna tersendiri. Penulis memiliki kesepemahaman dengan pendapat dari Kasali (2017) yang menyebutkan bahwa "disruption akan sangat mudah terjadi dalam industri yang highly regulated." Disrupsi yang memiliki ciri, destruktif dan kreatif. Setelah terjadinya disrupsi kita bisa mengamatinya dari cara melayani yang berubah dan akibatnya. Dengan demikian dapat dipahami mengapa mengatur tarnsportasi daring, seharusnya menggunakan pendekatan atau kaca mata yang berbeda dari pengaturan terhadap transportasi konvensional.

Alih-alih membuat peraturan yang lebih adaptif dengan keadaan zaman dan perubahan teknologi informasi, pemerintah masih berusaha mengatur transportasi daring sebagaimana mengatur transportasi konvensional. Hal ini dapat dilihat secara detail pada pasal-pasal yang mengatur keberadaan transportasi daring atau yang disebut sebagai angkutan sewa khusus (ASK) dalam Permenhub108/2017. Secara garis besar, peraturan transportasi khususnya taksi konvensional atau angkutan kota (Angkot) selama ini memiliki peraturan yang sangat menyulitkan para pengusaha, 
seperti perizinan, izin usaha, izin trayek, pembatasan wilayah operasi, dan sebagainya. Hal ini lah yang di destruksi oleh transportasi daring (Go-Jek dan Grab) melalui platform digital yang diusungnya.

Peraturan pertama yang dikeluarkan oleh pemerintah untuk mengatur transportasi daring adalah Permenhub 32/2016. Pemerintah sebenarnya telah memberikan pilihan kepada perusahaan aplikasi transportasi daring (aplikator) terkait jenis lini bisnisnya. Jika memang berada dalam wilayah perusahaan teknologi maka diharuskan untuk bekerja sama dengan perusahaan angkutan resmi atau membentuk koperasi atau badan hukum lainnya yang bekerja disektor transportasi. Namun pilihan untuk berubah atau beralih menjadi perusahaan jasa transportasi sepertinya enggan dilaksanakan oleh aplikator transportasi daring. Persoalan inilah kemudian yang sampai saat ini masih belum menemui titik temu antara pemerintah dan aplikator. Sementara itu, berbagai aksi demontrasi dan konflik terus meluas yang dilakukan oleh transportasi konvensional untuk menuntut keadilan. Mereka berharap pemerintah bisa bersikap adil dengan cara mengatur keberadaan transportasi daring.

Menanggapi berbagai aksi demonstrasi oleh pengemudi transportasi konvensional pemerintah melalui Menteri Perhubungan (Menhub) berencana akan merevisi Permenhub 32/2016 yang akan disahkan. Secara umum pengemudi transportasi konvensional menuntut keadilan dari pemerintah, karena transportasi daring dinilai terlalu diberi kelonggaran yang menyebabkan persaingan menjadi timpang. Pada tanggal 21 Maret 2017, Menteri Perhubungan mengumumkan akan melakukan revisi atas Permenhub 32/3016. Kemudian pada tanggal 1 April 2017 pemerintah mengumumkan revisi tersebut menjadi menjadi Permenhub 26/2017. Melalui peraturan terbaru pada saat itu, transportasi daring disebut sebagai Angkutan
Sewa Khusus (ASK). Terdapat setidaknya 11 poin yang mengatur transportasi daring, seperti batas kuota, batas tarif, STNK berbadan hukum, penyediaan pool, uji KIR, penyediaan bengkel, pajak akses dashboard, dan sanksi. Namun implementasi Permenhub 26/2017 ini tidak berlangsung lama.

Pemerintah seperti tidak menduga ketika enam orang pengemudi transportasi daring melakukan gugutan dengan mengajukan hak uji materiil terhadap sejumlah pasal pada Mahkamah Agung (MA) terhadap Permenhub 26/2017. Pada bulan Agustus 2017, MA membatalkan 14 pasal dalam Permenhub 26/2017 melalui putusan No. 37 P/HUM/ 2017. MA menilai Permenhub bertentangan dengan peraturan perundang-undangan diatasnya, seperti UU 20/2008 tentang Usaha Mikro Kecil dan Menengah (UMKM) dan UU 22/2009 tentang Lalu Lintas dan Jalan Raya (LLAJ). Pembatalan ini mengakibatkan tidak ada payung hukum bagi transportasi daring, dan membuat terjadi gejolak di beberapa daerah, seperti aksi demonstrasi di Jawa Timur yang dilakukan oleh Pengemudi Angkutan Kota (Angkot) dan pengemudi transportasi konvensional lainnya tidak terhindarkan.

Pembatalan 14 pasal dan 18 poin yang mengatur transportasi daring direspon oleh sejumlah kelompok pentingan transportasi konvensional dengan melakukan aksi demontrasi dan lain sebagainya. Pada 17 Oktober 2017 untuk meredam gejolak dan mendapatkan masukan terkait pengaturan transportasi daring, Menhub berencana akan menggelar pertemuan untuk berdialog dengan perwakilan taksi konvensional. Peraturan baru sebagai pengganti Permenhub 26/2017 harus segera diterbitkan maksimal pada 1 November 2017. Sebelum menggulirkan peraturan baru sebagai revisi atas Permenhub 26/2017, Menhub telah menggelar sejumlah pertemuan dengan berbagai kelompok kepentingan. Menhub menyatakan telah bertemu dengan tiga perusahaan aplikasi transportasi daring saat itu, seperti Uber, Go-Jek dan Grab. 
Saat ini perusahaan Uber di Asia Tenggara telah diakuisisi oleh Grab. Menhub juga telah menggelar dialog dengan Organisasi Pengusaha Angkutan Darat (Organda), dan perwakilan transportasi konvensional lainnya sebelum mengeluarkan peraturan terbaru tentang transportasi daring.

Menhub akhirnya dengan cepat, tepatnya pada tanggal 24 Oktober 2017, mengeluarkan revisi atas
Permenhub 26/2017 menjadi Permenhub 108/2018. Dijelaskan disela-sela pengesahannya bahwa Permenhub 108/2017 memiliki filosofi kesetaraan, yaitu kesetaraan transportasi konvensional dan transportasi daring. Kesetaraan mejadi penting menurut Menhub setidaknya untuk memastikan bahwa persaingan yang sempurna atau tidak timpang bisa terjadi. Menhub juga menyatakan

Tabel 2 : Perbandingan Permenhub 26/2017 dan Permenhub 108/2017

\begin{tabular}{|c|c|c|}
\hline Pengaturan & Permenhub 26/2017 & Permenhub 108/2017 \\
\hline $\begin{array}{l}\text { Penggunaan } \\
\text { Argometer }\end{array}$ & $\begin{array}{l}\text { Tarif berpatokan pada argometer } \\
\text { atau tertera pada aplikasi online }\end{array}$ & $\begin{array}{l}\text { Tarif tercantum pada argometer } \\
\text { atau aplikasi dengan dokumen } \\
\text { elektronik }\end{array}$ \\
\hline Batas Tarif & $\begin{array}{l}\text { Mematuhi tarif batas bawah dan } \\
\text { atas yang diusulkan gubernur dan } \\
\text { ditetapkan Kementerian Perhubungan }\end{array}$ & $\begin{array}{l}\text { Tarif berpedoman pada batas } \\
\text { bawah dan atas yang ditetapkan } \\
\text { Kementerian Perhubungan atas } \\
\text { usul daerah }\end{array}$ \\
\hline Wilayah Operasi & $\begin{array}{l}\text { Ditetapkan dengan } \\
\text { mempertimbangkan klasifikasi } \\
\text { perkotaan, perkembangan daerah, } \\
\text { dan tersedianya jalan }\end{array}$ & $\begin{array}{l}\text { Beroperasi pada wilayah operasi } \\
\text { yang ditetapkan oleh direktur } \\
\text { jenderal/Kepala BPTJ/Gubernur }\end{array}$ \\
\hline Kuota & $\begin{array}{l}\text { Kuota mempertimbangkan kebutuhan } \\
\text { dan potensi kenaikan pengguna. } \\
\text { Ditetapkan lima tahun dan ditinjau } \\
\text { setiap tahun }\end{array}$ & $\begin{array}{l}\text { Kebutuhan kendaraan ditetapkan } \\
\text { oleh Direktur Jenderal/Gubernur } \\
\text { dan diumumkan ke publik }\end{array}$ \\
\hline $\begin{array}{l}\text { Kepemilikan } \\
\text { Kendaraan }\end{array}$ & $\begin{array}{l}\text { Surat Tanda Nomor Kendaraan } \\
\text { atas nama perusahaan dengan } \\
\text { dokumen SRUT }\end{array}$ & $\begin{array}{l}\text { Boleh atas nama badan hukum } \\
\text { atau perorangan dan melampirkan } \\
\text { salinan SRUT. }\end{array}$ \\
\hline Batas Jumlah Armada & $\begin{array}{l}\text { Badan hukum memiliki paling sedikit } \\
\text { lima kendaraan atas nama badan } \\
\text { hukum }\end{array}$ & $\begin{array}{l}\text { Perorangan yang memiliki kurang } \\
\text { dari lima kendaraan membentuk } \\
\text { koperasi }\end{array}$ \\
\hline $\begin{array}{l}\text { Peran Perusahaan } \\
\text { Aplikasi }\end{array}$ & - & $\begin{array}{l}\text { Perusahaan aplikasi tidak boleh } \\
\text { bertindak sebagai penyelenggara } \\
\text { angkutan umum, seperti merekrut } \\
\text { pengemudi, menentukan tarif, } \\
\text { memberikan layanan akses aplikasi } \\
\text { kepada perorangan, dan memberikan } \\
\text { promosi tarif di bawah tarif batas } \\
\text { bawah yang telah ditetapkan }\end{array}$ \\
\hline
\end{tabular}

Sumber: Jawa Pos, 2017; Koran Tempo, 2017 (Data Diolah). 
bahwa seluruh perusahaan aplikator, Go-Jek dan Grab, dan Organda telah sepakat dengan poin-poin yang terdapat dalam Permenhub 108/2017.

Kejanggalan dalam proses perumusan kebijakan transportasi daring adalah sedikitnya atau minimnya pelibatan para pengemudi, baik konvensional maupun daring, serta pemasukan kembali beberapa pasal normatif yang telah dibatalkan oleh MA ke dalam Permenhub terbaru. Dampak yang dapat dilihat dengan kasat mata adalah penolakan Permenhub 108/2017 oleh sejumlah serikat pengemudi daring. Para pengemudi transportasi daring mulai memahami pentingnya berkelompok atau berserikat, sehingga saat ini terdapat beberapa kelompok pengemudi daring yang eksis. Masing-masing serikat pengemudi daring memiliki sikap dan pandangan yang berbeda terkait peraturan yang ada, fokus penerimaan dan penolakan mereka juga berbeda-beda.

Aliansi Nasional Driver Online (Aliando) menyatakan menolak Permenhub 108/2017 karena dinilai tidak mengakomodir aspirasi mereka. Setidaknya tiga kali aksi demontrasi telah dilakukan Aliando sepanjang pada 26 November 2017, 31 November 2017, dan 22 Januari 2018. Karena poin-poin usulan meraka tidak dimasukkan dalam revisi, maka mereka menolak Permenhub 108/2017. Aksi penolakan juga dilakukan oleh serikat pengemudi daring lainnya, seperti Front Driver Online Indonesia (FDOI), Organisasi Angkutan Sewa Khusus Indonesia (Oraski), dan lain sebagainya. Asosiasi Driver Online (ADO) sebagai salah satu serikat pengemudi daring yang cukup besar, memiliki sikap yang sedikit berbeda dalam beberapa isu atau poin dalam Permenhub 108/2017. Sehingga ADO tidak menolak Permenhub 108/2017 secara keseluruhan. Salah satu kelemahan dari proses perumusan kebijakan transportasi daring yang cukup substansial adalah pelibatan kelompok pentingan yang tidak menyeluruh. Berikut petikan pernyataan Fahmi selaku Sekretaris Jenderal Oraski.
"Kita sudah dari Permenhub 32, 26, dan saat ini 108 kelemahan Kemenhub setiap membuat peraturan yang diajak hanya komunitas yang tidak bersebrangan dengan pemerintah, artinya yang diajak hanya yang apa yang maunya dengan pemerintah dia nurut, padahal yang lebih banyak yang bersebrangan jadi memang tidak semuanya dilibatkan.. Kita maunya pemerintah itu buat aturan yang bener-bener yang adil gitu, yang melibatkan seluruh stakeholder (dalam Rizky, 2018).”

Gugatan terhadap Permenhub 108/2017 dilakukan oleh tiga orang warga Surabaya, yaitu Daniel Lukas Rorong, Hery Wahyu Nugroho dan Rahmatullah Riyadi. Gugutan tersebut dikabulkan oleh Majelis Hakim, sehingga terdapat beberapa pasal yang kembali dibatalkan. Putusan pembatalan beberapa pasal tersebut disampaikan pada $31 \mathrm{Mei}$ 2018. Adapun dasar untuk melakukan pembatalan dan mengabulkan permohonan pemohon adalah UU No. 8 Tahun 1999 tentang Perlindungan Konsumen dan UU No. 20 Tahun 2008 tentang Usaha, Mikro, Kecil dan Menengah (UMKM). Pembatalan sejumlah pasal oleh MA dilakukan karena Permenhub 108/2017 melakukan pemuatan ulang materi norma yang telah dibatalkan oleh MA melalui putusan Nomor 37/P HUM/2017, pada Permenhub 26/2017 sebelumnya.

Terdapat 11 pasal yang kembali dibatlkan oleh MA, dan ada satu pasal terdapat beberapa huruf dalam pasal yang dibatalkan lebih dari satu. Adapun beberapa pasal yang dibatalkan oleh MA, seperti pasal 6 ayat (1) huruf e tentang tarif angkutan berdasarkan argometer atau tertera pada aplikasi berbasis teknologi informasi, pasal 27 ayat (1) huruf d yang menyetakan bahwa kendaraan yang digunakan sebagai angkutan sewa khusus wajib menggunakan stiker pada kaca depan kanan atas dan belakang kanan atas dengan memuat wilayah operasi, pasal 27 ayat (1) huruf f tentang 
perlengkapan dokumen perjalanan yang sah, pasal 38 huruf a tentang kewajiban agar memperoleh izin sebagai perusahaan angkutan wajib memiliki minimal 5 kendaraan, pasal 40 tentang keharusan berhimpun dalam sebuah bdan hukum, pasal 65 huruf tentang pelarangan terhadap perusahaan aplikasi untuk bertindak sebagai penyelenggara angkutan umum yang melakukan rekrutmen pengemudi, dan sejumlah pasal lainnya.

Persoalan lintas kementerian dan lembaga untuk mengatur transportasi daring menjadi hal yang penting. Serikat pengemudi transportasi daring, seperti ADO dan Oraski misalnya telah memahami pentingnya pelibatan Kementerian Komunikasi dan Informatika (Kemenkominfo) untuk mengatur pihak aplikator transportasi daring. Karena hingga saat ini peraturan tentang transportasi daring masih hanya dikeluarkan oleh Kemenhub. Sebenarnya pemerintah sudah melakukan pertemuan lintas kementerian untuk mengatur transportasi daring, seperti pertemuan yang dilakukan oleh Kepala Staf Presiden, Menhub dan Menkominfo dengan Grab dan Go-Jek selaku aplikator transportasi daring yang mneyepakati akan dilakukan penaikan tarif (Sanusi Ed, 2018). Namun pertemuan tersebut bukan ditujukan dan tidak menghasilkan kesepakatan mengenai peraturan bersama tentang transportasi daring.

Kebijakan tentang transportasi daring masih akan menyisahkan pekerjaan rumah yang besar bagi pemerintah. Hal ini setidaknya menyangkut bagaimana sinkronisasi antar kementerian dan lembaga negara lainnya untuk mengatur dan melaksanakan kebijakan. Peraturan yang masih hanya dibuat oleh Kemenhub tidak akan cukup komprehensif untuk mengatur transportasi daring. Dibutuhkan peran serta dan keterlibatan kementerian dan lembaga negara lainnya untuk memastikan peraturan berjalan secara komprehensif. Hal ini diharapkan agar pemerintah tidak hanya sibuk menanggulangi masalah saja, melainkan juga dapat mengantisipasi masalah yang akan datang. Oleh karena itu perlu dibuat peraturan yang lebih komprehensif dan integratif, misalnya antara Kemenhub, Kemenkominfo, dan Kementerian Ketenagakerjaan, serta membentuk kebijakan transportasi yang lebih tangkas (agile) yang dapat menyesuaikan dengan perubahan.

\section{MASYARAKAT DIGITAL DAN TRANSPORTASI DARING}

Setiap tahun pengguna jaringan internet di Indonesia terus bertumbuh semakin besar. Besarnya pengguna jaringan internet di Indonesia adalah sebuah potensi tersendiri jika mampu terus dikembangkan. Hal ini menjadikan Indonesia menjadi salah satu pasar terbesar di dunia bagi pengembang platform digital. Perubahan ini turut serta merubah perilaku masyarakat dalam melakukan konsumsi barang dan jasa. Berikut adalah data pengguna jaringan internet di Indonesia dari tahun 2010 hingga 2017.

Tabel 3 : Data Pengguna Internet di Indonesia

\begin{tabular}{|c|r|}
\hline Tahun & Jumlah (Juta) \\
\hline 2010 & 42 \\
\hline 2011 & 55 \\
\hline 2012 & 63 \\
\hline 2013 & 82 \\
\hline 2014 & 88.1 \\
\hline 2015 & 110.2 \\
\hline 2016 & 132.7 \\
\hline 2017 & 143.3 \\
\hline Sumber: Asosiasi Penyelenggara Jasa Internet Indonesia \\
\hline
\end{tabular}


Dari data pada tabel 3 dapat dilihat bahwa dari tahun 2010 sampai dengan 2017 pengguna internet di Indonesia terus bertambah. Tahun 2010 pengguna internet di Indonesia masih sangat terbatas, yaitu 42 juta jiwa, namun angka ini melesat dalam lima tahun berikutnya menjadi 110,2 juta jiwa. Penghitungan terakhir pada tahun 2017 jumlah pengguna internet di Indonesia mencapai 143,3 juta jiwa atau lebih dari separuh jumlah penduduk Indonesia telah menggunakan jaringan internet. Dari jumlah pengguna internet di Indonesia tersebut, sebagian besar penetrasi pengguna internet masih di dominasi oleh masyarakat yang tingal di daerah urban, yaitu mencapai $72,41 \%$. Sementara itu penetrasi penguna internet di daerah rural-urban masih mencapai 49,49\%, dan daerah rural sebesar 48,25\% (APJII, 2017).

Tren kenaikan ini diprediksi masih akan terus terjadi hingga beberapa tahun mendatang. Indonesia memiliki jumlah penduduk lebih kurang 270 juta jiwa pada tahun 2018, dan merupakan negara keempat dengan jumlah penduduk terbesar di dunia. Dengan jumlah penduduk yang sangat besar membuat Indonesia memiliki pangsa pasar yang besar untuk pengembangan bisnis digital, salah satunya adalah transportasi daring. Hal ini terlihat dari besarnya pertumbuhan aplikator digital Indonesia, jika dilihat dari pengemudi dan nilai investasinya yang semakin besar. Jumlah pengemudi Go-Jek adalah lebih kurang 850 ribu dengan sebagian diantaranya lebih kurang 250 ribu pengemudi ojek pada tahun 2017, dengan nilai investasi mencapai sekitar 4 Miliar US Dollar atau sekitar Rp. 53 Triliun pada awal 2018. Sementara itu, pengemudi Grab di Asia Tenggara mencapai lebih kurang 1,2 juta dengan pengemudi ojek di Indonesia mencapai 150 ribu pada tahun 2017, kemudian nilai investasi Grab mencapai sekiar 6 Miliar US Dollar atau setara dengan Rp. 80 Triliun (Koran Kompas, 2018)

Martin (2008) menjelaskan masyarakat digital atau digital society sebagai masyarakat yang secara esensial dibentuk melalui perkembangan teknologi digital. Transportasi daring di Indonesia telah berhasil memberikan pengaruh terhadap kehidupan sosial berupa penggunaan transportasi publik, bagi yang sebelumnya terbiasa mengunakan transportasi pribadi maupun transporatsi publik lainnya. Pengaruh tersebut tidak bisa dielakkan adalah bagian integral dari perkembangan platform digital yang diusung oleh aplikator transportasi daring. Konsep sharing economy merupakan salah satu wacana yang sering kali dikedepankan, namun konsep tersebut masih debatable dalam hal fairness dan equity.

Daya ubah teknologi informasi ke dalam dunia bisnis transportasi telah sangat dirasakan pengaruhnya oleh pelaku usaha jasa transportasi konvensional. Untuk melihat perbedaan dan perubahan dari 'dunia lama' menuju 'dunia baru' dalam bahasa Kasali dunia baru tersebut disebut sebagai perabadan Uber, tabel berikut ini bisa menjelaskan secara ringkas.

Tabel 3 : Peradaban Uber

\begin{tabular}{|l|l|}
\hline \multicolumn{1}{|c|}{ Dunia Lama } & \multicolumn{1}{|c|}{$\begin{array}{c}\text { Dunia Baru } \\
\text { (Peradaban Uber) }\end{array}$} \\
\hline Time series dan linier & $\begin{array}{l}\text { Real time dan } \\
\text { eksponensial }\end{array}$ \\
\hline $\begin{array}{l}\text { On the Lane Economy } \\
\text { (menunggu pada } \\
\text { antrian) }\end{array}$ & $\begin{array}{l}\text { On Demand Economy } \\
\text { (begitu diinginkan, }\end{array}$ \\
\hline $\begin{array}{l}\text { Supply-Demand } \\
\text { tunggal }\end{array}$ & $\begin{array}{l}\text { Supply-Demand } \\
\text { dengan jejaring }\end{array}$ \\
\hline Lawannya jelas & $\begin{array}{l}\text { Lawan-lawan } \\
\text { tak terlihat }\end{array}$ \\
\hline
\end{tabular}

Sumber: Kasali (2016).

Dunia baru (Peradaban Uber/Peradaban Digital) yang ditopang oleh teknologi informasi telah menciptakan daya disrupsi yang sangat besar. Peradaban digital menuntut adanya efisiensi yang 
jauh lebih luwes melalui penciptaan jejaring dalam berbisnis. Go-Jek dan Grab di Indonesia telah berhasil menjadi penyedia platform digital bagi bertemuanya pemilik kendaraan atau penyedia jasa transportasi dengan pengguna jasa transportasi. Disini konsep kepemilikan atas modal berupa kendaraan tidak ditanggung oleh Go-Jek maupun Grab, sehingga konsep ekonomi berbagi menjadi dimungkinkan. Lawan yang harus dilawan dalam dunia digital tidak selalu terlihat dengan jelas, karena itu dalam dunia digital kita melawan lawan-lawan yang tidak terlihat. Tidak seperti bisnis dalam dunia lama, misalnya Blue Bird melawan Express. Platform Go-Jek dan Grab memungkinkan setiap orang berbagi tunpangan dan menjadi pengemudi tanpa harus terlihat secara kasat mata.

Piliang (2012) menjelaskan bahwa perkembangan dunia teknologi informasi telah berhasil menciptakan sebuah ruang baru yang bersifat artifisial dan maya, yaitu ruang siber (cyberspace). Ruang artifisial dan maya tersebut mempengaruhi kehidupan masyarakat yang mulai menggantungkan atau mensubstitusikan aktifitasnya kesehariannya dengan bantuan teknologi informasi. Hal inilah yang secara mengejutkan berhasil menciptakan bentuk masyarakat baru yang mungkin di kemudian hari akan berbeda dengan perabdan saat ini. Pengembangan teknologi yang kian cepat, seperti artificial intelligence (AI), computing cloud, blockchain, dan sebagainya, akan benar-benar mengubah secara mendasar peradaban manusia.

Perkembangan teknologi informasi yang kian cepat telah mengakibatkan migrasi sosial besarbesaran terjadi. Berbagai aktifitas sosial nyata telah bertransformasi menuju kehidupan maya, seperti cyber-social, cyber-community, cyber-sexuality, cyber-economy, cyber-politic, dan sebagainya. Dengan demikian perubahan sosial tidak terjadi secara kasat mata, namun memiliki dampak yang secara esensial sangat berpengaruh. Perubahan sosial dari perkembangan dunia digital tampak setidaknya dalam tiga tingkatan, yaitu individu, antar-individu, dan komunitas (Piliang, 2012). Perubahan dalam tiga tingkatan tersebut juga terjadi dalam perubahan yang diusung oleh transportasi daring.

Pada tingkat individu, perubahan yang terjadi dari adanya transportasi daring adalah berubahnya pola konsumsi. Individu lebih memiliki pilihan dalam menggunakan trasportasi publik dari yang telah tersedia selama ini, dengan kepastian harga, fleksibilitas, dan keterjangkauan yang sangat memadai. Memesan penyedia jasa transportasi daring hanya dengan melalui dawai jaringan internet melalui smartphone atau personal computer (PC). Seperti hal nya taksi, transportasi daring melayani pengguna jasa dari pintu ke pintu sehingga sangat dirasakan manfaatnya, misalnya efisiensi waktu. Diskon harga yang selama ini dilakukan oleh aplikator transportasi daring, membuat transportasi daring semakin terkenal di masyarakat. Dengan harga yang lebih murah dan pasti, membuat transportasi konvensional kehilangan pasarnya. Transportasi daring juga berhasil membuat individu yang sebelumnya tidak pernah atau jarang menggunakan transportasi publik menjadi menggunakan transportasi publik, yaitu transportasi daring.

Pada tingkat antar-individu, transportasi daring membuat konsep ekonomi berbagi dan supplydemand dalam jaringan menjadi dimungkinkan. Ekonomi berbagi antara aplikator dan pemilik kendaraan menjadikan relasi unik terjadi diantara keduanya, bukan seperti buruh dan majikan, lebih mendekati mitra. Meskipun konsepsi mitra disini masih cenderung merugikan atau menempatan pengemudi (pemilik kendaraan) sebagai pihak kasta terbawah. Permintaan dan penawaran dengan menggunakan platform digital (Go-Jek dan Grab) menjadi pasar yang sangat potensial dan besar dalam mempertemukan penyedia jasa dan pengguna jasa. Platform inilah yang secara esensial membedakan transportasi daring dan transportasi konvensional. 
Perubahan dalam tingkat komunitas dapat dilihat dari terbentukya berbagai komunitas, misalnya komunitas pengemudi transportasi daring yang di dasarkan atas kesamaan profesi sebagai pengemudi daring. Ralasi hubungan kerja semi-informal yang terbentuk dari sistem kemitraan dalam transportasi daring berhasil memberikan warna tersendiri. Para pengemudi yang mulai sadar akan pentingnya berkomunitas mulai menggalang berbagai organisasi atau komunitas untuk menyampaikan aspirasi mereka. Para pengemudi menuntut perbaikan dalam konteks keadilan sistem bagi hasil yang selama ini berlangsung. Perubahan ini terlihat berbeda dalam pola bisnis lama yang diusung oleh transportasi konvensional, sehingga perubahan ini penting untuk diperhatikan oleh pelaku usaha dan pemerintah sebagai regulator.

\section{KESIMPULAN}

Dinamika kebijakan transportasi daring telah memberikan tantangan terhadap kebijakan publik. Dibutuhkan kebijakan publik yang sesuai dengan semangat zaman di era disrupsi, karenanya dibutuhkan kebijakan publik yang tangkas (agile). Selain itu, kebijakan publik yang lebih terintegrasi dan komprehensif dibutuhkan untuk mengatur keberadaan transportasi daring, pemerintah tidak boleh absen dalam urusan transportasi publik. Pelibatan lintas kementerian dan lembaga negara sangat dibutuhkan untuk menjamin kebijakan yang dirumusakan serta pelaksanaanya bisa maksimal. Pemerintah perlu melibatkan berbagai stakeholder ketika perumusan kebijakan berlangsung. Pelibatan stakeholder penting untuk menjamin setiap aspirasi kelompok kepentingan dapat terwadahi dan dapat ditemukan satu titik temu bersama.

Pengguna internet di Indonesia dari tahun ke tahun selalu mengalami peningkatan. Diperkirakan peningkatan pengguna internet ini masih akan terus terjadi pada tahun-tahun mendatang. Pengguna internet adalah masyarakat yang sudah mulai menggunakan bantuan teknologi digital untuk memenuhi kebutuhan atau dalam mendukung aktifitas kesehariannya. Hal inilah yang membuat terbentunya masyarakat digital di Indonesia, salah satunya adalah transportasi daring yang menggunakan jaringan internet dan perangkat digital.

Tingginya pengguna internet di Indoneisa memberikan keuntungan bagi perkembangan dunia bisnis digital, salah satunya transportasi daring. Keberadaan transportasi daring telah memberikan pengaruh terhadap perubahan sosial. Perubahan itu terlihat pada tiga tingkatan, yaitu tingkat individu, antar-individu, dan komunitas. Pada tingkat individu, transportasi daring mampu memberikan pengaruh terhadap gaya konsumsi transportasi masyarakat di Indonesia. Pada tingkat antar-individu, masyarakat bisa ikut serta dalam bisnis transportasi dengan menggunakan kendaraan pribadinya yang digunakan sebagai kendaraan umum untuk mengangkut penumpang. Keikutsertaan ini disebut sebagai ekonomi berbagi. Pada tingkat komunitas, pengemudi transportasi daring mulai menyadari pentingnya membentuk organisasi atau komunitas untuk menyampaikan aspirasi mereka. Posisi pengemudi, dalam bentuk bisnis transportasi konvensional dan transportasi daring tentu berbeda, sehingga terjadilah perubahan sosial. 


\section{DAFTAR PUSTAKA}

Mercier, Jean. 2009. Equity, Social Justice, And Sustainable Urban Transportation in The Twenty-First Century. Administrative Theory \& Praxis, Vol. 31, No. 2, hal. 145163, DOI: 10.2753/ATP1084-1806310201.

Wahyuningtyas, S. Y. 2016. The Online Transportation Network in Indonesia: A Pendulum between the Sharing Economy and Ex Ante Regulation. Competition and Regulation in Network Industries, 17(3-4), hal. 260-280. doi: 10.1177/178359171601700304.

Darmawati. 2018. Gender dan Ekonomi (Analisa Terhadap Mitra Go-Jek Perempuan di Indonesia Tahun 2018). Jurnal Al-Wardah, Vol. 11, No. 1 hal. 1-20.

Ramadhan, M. Teza R. 2017. Pengaruh Produktivitas Tenaga Kerja Jasa Transportasi Daring Terhadap Kesejahteraan Tenaga Kerja (Studi pada Tenaga Kerja Pengemudi Go-Jek di DKI Jakarta). Skripsi Univeristas Brawijaya: Tidak Diterbitkan.

Samudro, Jagad. 2017. Analisis Perbandingan Kebijakan Jakarta dan Singapura di Bidang Transportasi Daring. Skripsi Universitas Gadja Mada: Tidak Diterbitkan.

Qisti, Febrian A. 2018. Analisis Pendapatan Sopir Angkutan Kota (Angkot) di Kota Surakarta Serta Perbedaan Pendapatan Sebelum dan Sesudah Adanya Transportasi Daring (Online). Skripsi Universitas Muhammadiyah Surakarta: Tidak Diterbitkan.

Putri, Jovita. 2018. Uber dan Industri Jasa Transportasi di Indonesia. Skripsi Universitas Katolik Parahyangan: Tidak Diterbitkan.

Istianto, Bambang dan Taufan Mualamin. 2017. Kebijakan Transportasi On Line dan Konflik Sosial. Jurnal Ilmu Adminitrasi Negara (ASIAN), Vol. 5, No. 2, ISSN 2338-9567.

Nastiti, Aulia. 2016. Drivers' Stories Reveal How Exploitation Occurs in Gojek, Grab and Uber. Diakses pada 22-09-2018 pada https://theconversation.com/drivers-storiesreveal-how-exploitation-occurs-in-gojekgrab-and-uber-82689.

Koran Kompas. 2017. Pemerintah Berikan Keadilan (Sejumlah Unjuk Rasa Menolak Transportasi Daring di Daerah). 22 Maret 2017. Jakarta: Koran Kompas.

Kasali, Rhenald. 2017. Disruption. Jakarta: PT Gramedia Pustaka Utama.

Toffler, Alvin. 1980. The Third Wave. New York: Morrow.
Asosiasi Penyelenggara Jasa Internet Indonesia (APJII). 2017. Penetrasi dan Perilaku Pengguna Internet Indonesia. Teknopreneur dan APJII, Diakses pada http://apjii.or.id/survei2017 pada 24 September 2018.

Kresna, Mawa. 2017. Sopir Taksi Online Menanggung Tua Di Jalan Tanpa Jaminan. Diakses dari https://tirto.id/sopir-taksionline-menanggung-tua-di-jalan-tanpajaminan-cmbP tanggal 18-8-2018.

Koran Kompas. 2018. Bisnis Ekonomi Berbagi yang Tidak Adil (Perusahaan aplikasi Menyatakan, Mereka Berbagi Hak, Tanggung Jawab, dan Hasil dengan Mitra Pengojek Daring). Namun Pembagian itu Jauh Dari Adil). Tanggal 3 April 2018. Jakarta: Koran Kompas.

Rizky, Fahreza. 2018. Ini Alasan Organisasi Angkutan Sewa Tolak Permenhub 108. Diakses dari https://news.okezone.com/ $\mathrm{read} / 2018 / 01 / 29 / 338 / 1851537 /$ inialasanorganisasi-angkutan-sewa-tolak-permenhub108? Tanggal 23-8-2018.

Jawa Pos. 2017. Taksi Online Harus Berstiker. 20 Oktober 2017. Surabaya: PT Jawa Pos Koran.

Koran Tempo. 2017. Taksi Online Tak Lagi Murah. 20 Oktober 2017. Edition No. 5665, tahun XVII. Jakarta Selatan: Koran Tempo.

Martin, Allan. 2008. Digital Literacy and the "Digital Society". Dalam Colin Lankshear dan Michelle Knobel, Digital Literacies: Concepts, Policies and Practices, Hal 151-176. Diakses pada http://digitalfuturesoer3.pbworks.com tanggal 26-9-2018.

Piliang, Yasraf Amir. 2012. Masyarakat Informasi dan Digital: Teknologi Informasi dan Perubahan Sosial. Jurnal Sosioteknologi, Edisi 27, Hal. 143-156.

Koran Kompas. 2018. Penundaan Penerapan Aturan Kontraproduktif. Tanggal 2 April 2018. Jakarta: Koran Kompas.

\section{Peraturan Perundang-Undangan}

Undang-Undang (UU) No. 22 tahun 1999 tentang lalu Lintas dan Angkutan Jalan.

Peraturan Menteri Perhubungan (Permenhub) No. 26 tahun 2017 tentang Penyelenggaraan Angkutan Orang Dengan Kendaraan Bermotor Umum Tidak Dalam Trayek.

Peraturan Menteri Perhubungan (Permenhub) No. 108 tahun 2017 tentang Penyelenggaraan Angkutan Orang Dengan Kendaraan Bermotor Umum Tidak Dalam Trayek. 